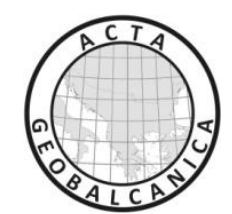

\title{
RELATIONS BETWEEN THE PROCESS OF LAND CONSOLIDATION AND SOCIO-ECONOMIC CONDITIONS IN MUNICIPALITIES IN LOWER SILESIA
}

\author{
Malgorzata Dudzińska $^{1} \&$ Lech Kotlewski ${ }^{1}$ \\ ${ }^{1}$ University of Warmia and Mazury in Olsztyn, Poland \\ Corresponding author: gosiadudzi@uwm.edu.pl
}

\begin{abstract}
One of the major problems in the CEE countries is land fragmentation. It varies considerably among these countries. Consolidation of agricultural land can be an effective solution of structural problems caused by land fragmentation.

It should be remembered, however, that consolidation of agricultural land is a complex procedure covering not only the technical aspect of the design of a new governance structure itself, but also the related legal aspects. The implementation of land consolidation also requires the involvement of residents - participants of the procedure. In Poland, the problem with the implementation of the procedure of agricultural land consolidation concerns the entire area of the country. In three voivodships: Lubelskie, Podkarpackie, and Małopolskie, quite many consolidations have been implemented (over more than 20,000 ha). In other three voivodships, no consolidations of agricultural land have been implemented, namely the Zachodniopomorskie, Warmińsko-Mazurskie, and Kujawsko-Pomorskie Voivodships. Why?
\end{abstract}

The article attempts to provide answers to the following questions: Does a correlation exist between the level of socio-economic conditions in municipalities and the scale of implemented consolidations of agricultural land in their areas? What is the level of socio-economic conditions in municipalities where agricultural land consolidations have been implemented?

The study involved the analysis and synthesis of the literature, and research based on a spatial-statistical approach. The study area covered the municipalities of the Dolnoślaskie Voivodship where agricultural land consolidations were implemented in the years 2004-2013.

Keywords: Land consolidation, socio-economic conditions, rural commune.

\section{INTRODUCTION}

One of the major problems in the CEE countries is land fragmentation. It varies considerably among these countries $[1,2,3]$. In Europe, the major causes of land fragmentation have been traditionally attributed to an increase in population, laws of inheritance, and poverty [4]. As throughout Eastern Europe, land fragmentation occurred as a side effect of the land privatisation process [5]. 
Recent experience from Moldova and a number of other CEE countries shows that voluntary land consolidation instruments can be successful in addressing structural problems caused by land fragmentation when integrated in a broader local rural development context [5].

Land consolidation measures should promote all dimensions of development. According to Dacko (2006), the main goal of land consolidation should be to improve the quality of rural life, and not only to increase agricultural production. Land consolidation measures should be initiated to revive the countryside by encouraging continuous economic and political development of the local community, while protecting and rationally managing natural resources.

It should be remembered that agricultural land consolidation is a complex procedure covering not only the technical aspects of the design of a new governance structure itself, but also the related legal aspects [1]. The implementation of land consolidations also requires the involvement of the residents - participants of the procedure, who frequently show a reluctant attitude towards agricultural land consolidations.

The procedure is therefore introduced in a given country at the first stage in the form of a pilot project, and at the next stage as a consolidation programme. Table 1 presents countries of Central and East Europe where consolidations and pilot projects are implemented (Table 1).

Table 1. Status of the development of land consolidation in Central and Eastern Europe shown in three categories (October 2014).

Source: own study based on Hartvigsen [3]

\begin{tabular}{|c|c|c|}
\hline $\begin{array}{l}\text { Ongoing land } \\
\text { consolidation programmes }\end{array}$ & $\begin{array}{l}\text { Introduction of land consolidation but not } \\
\text { yet a programme }\end{array}$ & $\begin{array}{l}\text { Little or no land } \\
\text { consolidation experience }\end{array}$ \\
\hline $\begin{array}{l}\text { Poland, Czech Republic, } \\
\text { Slovakia, Eastern } \\
\text { Germany, Slovenia, } \\
\text { Lithuania, Serbia. }\end{array}$ & $\begin{array}{l}\text { Estonia, Latvia, Hungary, Romania, } \\
\text { Bulgaria, Croatia, FYR of Macedonia, } \\
\text { Kosovo, Bosnia and Herzegovina, Albania, } \\
\text { Moldova, Armenia, Ukraine. }\end{array}$ & $\begin{array}{l}\text { Montenegro, Georgia, } \\
\text { Azerbaijan, Russian, } \\
\text { Federation Belarus. }\end{array}$ \\
\hline
\end{tabular}

In Poland, however, the works are implemented with varied intensity [6]. From 2004 to 2013, agricultural land consolidations were implemented in Poland over an area of 118 thousand hectares. The highest number of them was implemented in 2013. This probably resulted from the fact that 2013 was the last year of the Rural Development Programme 2007-2013.

The highest number of consolidations was implemented in the Lubelskie, Podkarpackie, and Małopolskie Voivodships - more than 20,000 ha each. In other three voivodships, no agricultural land consolidations were implemented, namely Warmińsko-Mazurskie, Zachodniopomorskie, and Kujawsko-Pomorskie Voivodships (Fig. 1). In spite of the implementation of consolidations over quite a large area, they only constitute $0.6 \%$ of agricultural land in Poland. In the Małopolskie Voivodship, the contribution amounts to $2.26 \%$ of the area of agricultural land, in the Podkarpackie Voivodship $-2.15 \%$, Ślaskie Voivodship $1.62 \%$, and Lubelskie Voivodship $-1.56 \%$. In the remaining voivodships, the contribution is lower than $1 \%$. 

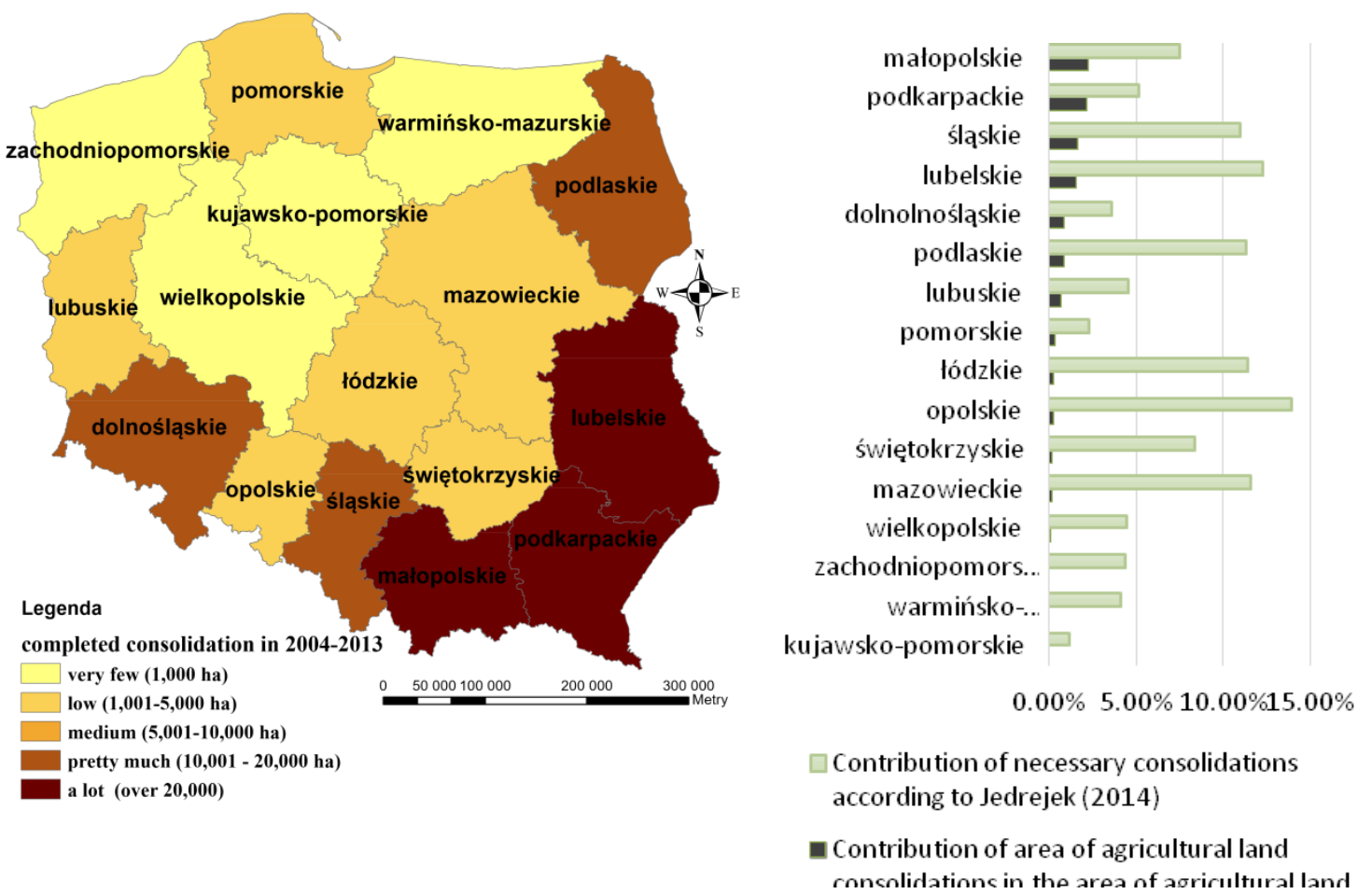

Figure 1. Implementation of consolidation of agricultural land in Poland in 2004-2013 and Contribution of implemented consolidations in the area of agricultural land by voivodship in comparison to the needs of implementation of "necessary" consolidations.

Source: Own compilation based on information from the Ministry of Agriculture and Rural Development and Jędrejek [7, 8].

The areas of implemented consolidations are inconsiderable in comparison to the determined needs. According to Jędrejek et al. [8], the level of "necessary" works (in villages where due to unfavourable land structure farmers lose at least $20 \%$ of income) varies from $1.2 \%$ in the Kujawsko-Pomorskie Voivodship to $13.9 \%$ in the Opolskie Voivodship (Fig. 1). The obtained data (Fig. 1.) suggests that the level of actually implemented consolidations does not correspond with the level of necessary consolidation measures (coefficient of correlation 0.194).

The article attempts to provide answers to the following questions: Does a correlation exist between the level of socio-economic conditions in municipalities and the scale of agricultural land consolidations implemented in their areas? What is the level of socioeconomic conditions in municipalities where agricultural land consolidations have been implemented?

\section{STUDY METHODS}

The study involved the analysis and synthesis of the literature, and research based on a spatial-statistical approach. The study area covered the municipalities of the Dolnośląskie Voivodship where agricultural land consolidations were implemented in the years 2004-2013. The first stage of the study involved the description of the implementation of consolidation measures in the municipalities of the Dolnoślasskie Voivodship. 
The second stage involved the assessment of socio-economic conditions in the municipalities of the Dolnośląskie Voivodship where consolidation works have been implemented. Then, correlations were analysed between the level of socio-economic conditions of municipalities and the area of consolidations implemented in a given municipality. The final stage involved drawing conclusions based on the performed research.

\section{Stage I. Implementation of agricultural land consolidations in the Dolnośląskie Voivodship.}

\section{Study area}

The Dolnośląskie Voivodship is located in the south-western part of Poland. The voivodship occupies an area of 19,948 $\mathrm{km} 2$, constituting $6.4 \%$ of the area of the entire country. It is the seventh largest of the 16 voivodships. Out of the total area of the region, $29.4 \%$ is occupied by forests and forestry land, and $52.8 \%$ by cultivated agricultural land. The proportions are similar to those occurring in other parts of the country. The contribution of agricultural land in the Dolnośląskie region considerably exceeds the mean value for the countries of the European Union, amounting to $40.9 \%$ of the total area. Moreover, $3.6 \%$ of the total area of the voivodship is occupied by transportation areas, and $2.6 \%$ by residential areas [9].

The Dolnośląskie Voivodship is largely varied in terms of conditions for conducting agricultural activity. This is determined by natural (quality of soils) and climatic conditions, as well as land use structure. Agricultural land in 2004 constituted $52.8 \%$ of the total area of the voivodship (mean for the country - 52.1\%). Its structure is dominated by cultivated land $(82.6 \%$ against $77.3 \%$ in the country). Grasslands (meadows and pastures) occupy $16.7 \%$ of the area of agricultural land (in the country $20.3 \%$ ). In general, agricultural land occupies $43.6 \%$ of the total area of the region (in the country $-40.3 \%$ ). Out of almost 870 thousand hectares of cultivated land of Lower Silesia, only approximately $8 \%$ constitutes land of bonitation classes I and II. Cultivated land under governance of individual farms constituted $76.3 \%$ in 2004 (mean for the country $-86.7 \%$ ). Its contribution is relatively low, resulting in the $13^{\text {th }}$ place among 16 voivodships of the country in these terms [9].

Table 2. Implementation consolidation of agricultural land in Lower Silesia.

Source: Own compilation based on Dudzińska [6]

\begin{tabular}{|l|l|l|l|}
\hline Lp. & Name of object & Municipality & $\begin{array}{l}\text { Surface area of the } \\
\text { consolidation object }\end{array}$ \\
\hline 1 & Krajów & Krotoszyce & 540,21 ha \\
\hline 2 & Nowa Wieś Złotoryjska & Złotoryja & 1201,95 ha \\
\hline 3 & Witoszyce i Chróścina & Góra & 1245,95 ha ; 1433,21 ha \\
\hline 4 & Zbaków Dolny i Górny & Wąsosz & 445,71 ha \\
\hline 5 & Milikowice & Jaworzyna Śląska & 947,42 ha \\
\hline 6 & Mściwojów & Mściwojów & 839,83 ha \\
\hline 7 & Krzydlina Mała i Krzydlina Wielka & Wołów & 1083,30 ha $; 1034,21$ ha \\
\hline 8 & Szklary Dolne & Chocianów & 1262,51 ha \\
\hline 9 & Koźlice & Gaworzyce & 587,46 ha \\
\hline 10 & Dobrocin & Dzierżoniów & 1245,88 ha \\
\hline
\end{tabular}


In the period 2004-2013, 12 objects of agricultural land consolidation were implemented with a total area of 11,867.64 ha (Table 2). The implemented objects were located in the area of 10 municipalities. Two consolidation objects were implemented in each of the Góra and Wołów Municipalities. The largest area covered by consolidation proceedings is located in the Góra Municipality $(2,679.16$ ha in total), and the smallest in the Wąsosz Municipality (445.71 ha). Although the implementation of consolidation measures covered almost 12 thousand ha of land, the area constitutes less than $1 \%$ of the agricultural land in the Dolnośląskie Voivodship.

\section{Stage II. Assessment of socio-economic conditions in the municipalities of the Dolnośląskie Voivodship where consolidation works have been implemented.}

Factors characterising socio-economic conditions include internal (endogenic) and external (exogenic) factors. It is commonly believed that particularly endogenic factors provide the basis for the development of local economy [10]. Parysek [10] includes conditions generated by the needs of the local community, as well as by possibilities related to local resources in local determinants of development. These include among others demographic and social transformations, local conditions of development, and urbanisation. The factors are presented in economic, social, and environmental categories [10]. The research was based on statistical data collected in the Statistical Office in Wrockaw in the scope of the Statistical Vademecum of the Local Government 2014 and 2015. The research covered 11 variables divided into four information groups (Table 3). The factors adopted for the study have the character of stimulants, and are indicators of the structure and intensity of phenomena.

Table 3. Set of variables adopted for the analysis of the socio-economic conditions of the Dolnośląskie Voivodship.

Source: Own compilation

\begin{tabular}{|c|c|c|c|c|c|c|}
\hline 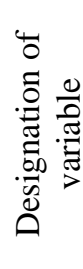 & 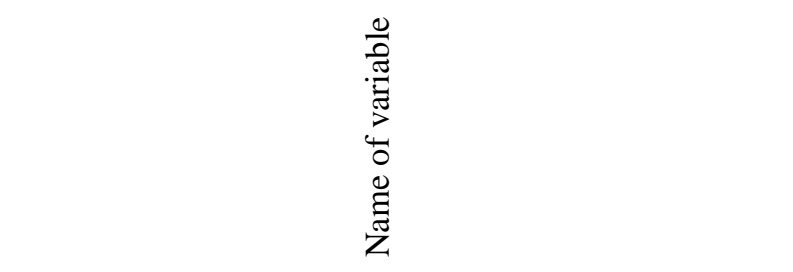 & $\underset{x}{x}$ & $\underset{x}{\stackrel{*}{*}}$ & 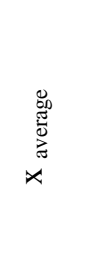 & 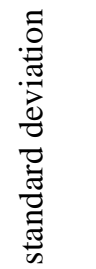 & 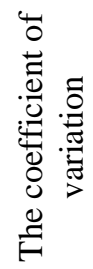 \\
\hline \multicolumn{7}{|c|}{ Demographic variables } \\
\hline $\mathbf{x}_{1}$ & Number of population per $1 \mathrm{~km}^{2}$ (population density) & 38 & 154 & 67,1 & 30,9 & $46 \%$ \\
\hline $\mathbf{x}_{2}$ & $\begin{array}{l}\text { Number of population at non-productive age per } 100 \\
\text { people at productive age }\end{array}$ & 51,1 & 59,1 & 54,6 & 2,7 & $5 \%$ \\
\hline $\mathbf{x}_{\mathbf{3}}$ & Number of employed people per 1000 people & 51 & 187 & 110 & 42,9 & $39 \%$ \\
\hline $\mathbf{x}_{4}$ & $\begin{array}{l}\text { Contribution of the registered unemployed in the } \\
\text { number of population at productive age [\%] }\end{array}$ & 4,9 & 11,6 & 9,11 & 2,2 & $24 \%$ \\
\hline \multicolumn{7}{|c|}{ Economic variables } \\
\hline $\mathbf{x}_{5}$ & $\begin{array}{l}\text { Total income of the budget of municipality per } 1 \\
\text { resident in PLN }\end{array}$ & 2723 & 4143 & 3326 & 434,6 & $13 \%$ \\
\hline $\mathbf{x}_{6}$ & $\begin{array}{l}\text { Total expenditures of the budget of municipality per } 1 \\
\text { resident in PLN }\end{array}$ & 2638 & 4222 & 3426 & 513,3 & $15 \%$ \\
\hline \multicolumn{7}{|c|}{ Variables from the scope of social infrastructure } \\
\hline $\mathbf{x}_{7}$ & Residences commissioned per 1000 residents & 12 & 46 & 21,8 & 9,4 & $43 \%$ \\
\hline $\mathbf{x}_{8}$ & Entities in the REGON register & 1044 & 1411 & 1231 & 119,6 & $10 \%$ \\
\hline \multicolumn{7}{|c|}{ Variables from the scope of technical infrastructure } \\
\hline $\mathbf{x}_{9}$ & Percentage of population using water supply utilities & 90,1 & 100 & 97,18 & 3,1 & $3 \%$ \\
\hline
\end{tabular}




\begin{tabular}{|l|l|l|l|l|l|l|}
\hline $\mathbf{x}_{\mathbf{1 0}}$ & Percentage of population using sewing utilities & 25,2 & 90,2 & 63,33 & 21,7 & $34 \%$ \\
\hline $\mathbf{x}_{\mathbf{1 1}}$ & Percentage of population using gas utilities & 0 & 61,2 & 33,83 & 21,4 & $63 \%$ \\
\hline
\end{tabular}

Diagnostic characteristics were selected from among variables adopted for the analysis. For this purpose, mutual correlations were analysed between variables adopted for the study. Normalisation of diagnostic characteristics was performed by the unitarisation method, with the application of the following formula:

$$
x_{i}^{\prime}=\left(\frac{x_{i}-A}{B}\right)^{p} \text { for } i=1,2, \ldots, 17
$$

where $\mathrm{x}_{\mathrm{i}}{ }^{\prime}$ - normalised value of $\mathrm{i}^{\text {th }}$ element of characteristic $\mathrm{X}$

$\mathrm{x}_{\mathrm{i}}-$ value of $\mathrm{i}^{\text {th }}$ element of characteristic $\mathrm{X}$ before normalisation

$$
A=\left\{\begin{array}{l}
0 \\
x_{\max }, \quad B=x_{\max }-x_{\min } \quad p=1 \\
x_{\min }
\end{array}\right.
$$

All of the selected diagnostic characteristics have the character of stimulants. The reduction of the multi-characteristic space was performed by method of standardised sums [11]. A synthetic metaindex was calculated presenting the total value of standardised diagnostic characteristics [12].

Variables describing socio-economic conditions are of demographic, economic character, and are related to the social and technical infrastructure occurring in the analysed area of the studied municipalities. Preliminary analyses showed that the highest variability among the factors adopted for the study occurs in the case of variable $\mathrm{x}_{11}$ - the percentage of population using gas utilities (Table 3). The municipalities are also differentiated by variable $\mathrm{x}_{7}$ - residences commissioned per 1000 people, and $\mathrm{x}_{1}-$ number of people per $1 \mathrm{~km}^{2}$ (population density). Correlations were calculated between the characteristics adopted for the study (Table 4).

Table 4. Matrix of Pearson's coefficients of correlation calculated between variables adopted for the analyses, data as at 2014.

Source: own elaboration based on data of the Central Statistical Office.

\begin{tabular}{|r|r|r|r|r|r|r|r|r|r|r|r|}
\hline & \multicolumn{1}{c|}{ x1 } & \multicolumn{1}{c|}{ x2 } & \multicolumn{1}{c|}{ x3 } & \multicolumn{1}{c|}{ x4 } & \multicolumn{1}{c|}{ x5 } & \multicolumn{1}{c|}{ x6 } & \multicolumn{1}{c|}{ x7 } & \multicolumn{1}{c|}{ x8 } & \multicolumn{1}{c|}{ x9 } & \multicolumn{1}{c|}{ x10 } & \multicolumn{1}{c|}{ x11 } \\
\hline x1 & $\mathbf{1 , 0 0 0}$ & $-0,160$ & 0,673 & $-0,404$ & $-0,526$ & $-0,513$ & 0,119 & 0,040 & 0,109 & $-0,307$ & 0,005 \\
\hline $\mathrm{x} 2$ & $-0,160$ & $\mathbf{1 , 0 0 0}$ & 0,070 & 0,511 & 0,105 & 0,106 & $-0,543$ & $-0,022$ & $-0,397$ & $-0,400$ & $-0,014$ \\
\hline $\mathrm{x} 3$ & 0,673 & 0,070 & $\mathbf{1 , 0 0 0}$ & 0,177 & $-0,561$ & $-0,561$ & $-0,064$ & 0,349 & $-0,151$ & $-0,056$ & 0,130 \\
\hline $\mathrm{x} 4$ & $-0,404$ & 0,511 & 0,177 & $\mathbf{1 , 0 0 0}$ & $-0,048$ & 0,009 & $-0,682$ & 0,525 & $-0,127$ & 0,015 & 0,113 \\
\hline $\mathrm{x} 5$ & $-0,526$ & 0,105 & $-0,561$ & $-0,048$ & $\mathbf{1 , 0 0 0}$ & 0,930 & 0,253 & 0,100 & 0,267 & 0,333 & $-0,370$ \\
\hline $\mathrm{x} 6$ & $-0,513$ & 0,106 & $-0,561$ & 0,009 & 0,930 & $\mathbf{1 , 0 0 0}$ & 0,218 & 0,092 & 0,143 & 0,353 & $-0,292$ \\
\hline $\mathrm{x} 7$ & 0,119 & $-0,543$ & $-0,064$ & $-0,682$ & 0,253 & 0,218 & $\mathbf{1 , 0 0 0}$ & $-0,037$ & $-0,136$ & 0,143 & $-0,078$ \\
\hline $\mathrm{x} 8$ & 0,040 & $-0,022$ & 0,349 & 0,525 & 0,100 & 0,092 & $-0,037$ & $\mathbf{1 , 0 0 0}$ & 0,243 & 0,002 & $-0,153$ \\
\hline $\mathrm{x} 9$ & 0,109 & $-0,397$ & $-0,151$ & $-0,127$ & 0,267 & 0,143 & $-0,136$ & 0,243 & $\mathbf{1 , 0 0 0}$ & 0,421 & $-0,020$ \\
\hline $\mathrm{x} 10$ & $-0,307$ & $-0,400$ & $-0,056$ & 0,015 & 0,333 & 0,353 & 0,143 & 0,002 & 0,421 & $\mathbf{1 , 0 0 0}$ & 0,394 \\
\hline $\mathrm{x} 11$ & 0,005 & $-0,014$ & 0,130 & 0,113 & $-0,370$ & $-0,292$ & $-0,078$ & $-0,153$ & $-0,020$ & 0,394 & $\mathbf{1 , 0 0 0}$ \\
\hline
\end{tabular}


The strongest correlation was determined between economic variables describing income and expenditures of the budget per 1 resident $\left(\mathrm{x}_{5}\right.$ and $\left.\mathrm{x}_{6}\right)$. The correlation is positive. This means that with an increase in income of budgets of municipalities, expenditures per 1 resident also increase. A strong correlation $(0.682-$ negative) was also determined between variables $\mathrm{x}_{4}$ and $\mathrm{x}_{7}$, i.e. between the contribution of the registered unemployed in the number of population at productive age and residences commissioned per 1000 residents. This means that with an increase in the number of the unemployed, the number of commissioned residences decreases. A similarly strong correlation occurs between population density $\left(\mathrm{x}_{1}\right)$ and the number of employed people per 1000 people $\left(\mathrm{x}_{3}\right)$. In this case, the Pearson's coefficient of correlation amounts to 0.673 (Table 4).

Diagnostic characteristics were selected based on the calculated values of coefficients of variance and Pearson's coefficients of correlation. A diagnostic characteristic should be characteristic of the analysed phenomenon, and show high variability. It is also advisable that it is strongly correlated with non-diagnostic characteristics from its information group, and weakly correlated with other characteristics considered diagnostic. The following diagnostic characteristics were selected based on the above criteria: $\mathrm{x}_{1}$ - population density, $\mathrm{x}_{6}$ - expenditures of the budget of municipality per 1 resident, $\mathrm{x}_{7}$ - residences commissioned per 1000 residents, and $\mathrm{x}_{11}$ - percentage of population using gas utilities. Further analyses were conducted based on selected diagnostic characteristics. They were standardised. Then, metaindices were calculated, constituting the total of standardised diagnostic characteristics, presented for the analysed municipalities in Table 5. Adopting the natural division of the metaindices, four class intervals were designated describing the degree of development of socioeconomic conditions (very weak, weak, good, and very good).

Table 5. Comparison of synthetic metaindices characterising socio-economic conditions in the analysed municipalities.

Source: Own compilation

\begin{tabular}{|c|c|c|c|c|c|}
\hline 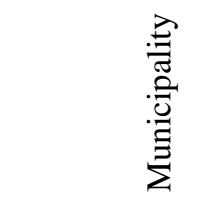 & 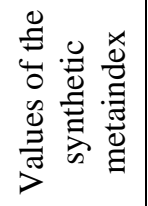 & 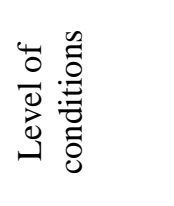 & 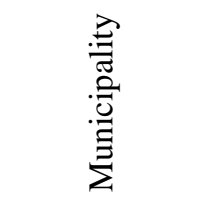 & 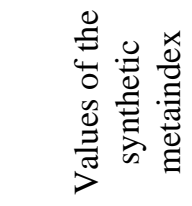 & 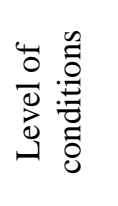 \\
\hline Krotoszyce & 2,485 & good & Mściwojów & 1,073 & weak \\
\hline Złotoryja & 1,262 & weak & Wołów & 1,901 & weak \\
\hline Góra & 1,893 & weak & Chocianów & 1,328 & weak \\
\hline Wąsosz & 0,774 & very weak & Gaworzyce & 2,117 & good \\
\hline Jaworzyna Śl. & 1,879 & weak & Dzierżoniów & 1,185 & weak \\
\hline
\end{tabular}

In the synthetic approach, the index of socio-economic conditions was the most favourable in the case of two municipalities, i.e. Krotoszyce and Gaworzyce (consolidations were implemented there over an area of 540 ha and 587 ha), and the worst in reference to the Wąsosz Municipality (agricultural land consolidations were implemented there over an area of 445 ha) (Table 5). 


\section{CONCLUSIONS}

The studied municipalities are distinguished by varied level of socio-economic conditions, from very weak to good level. The socio-economic variability of the analysed municipalities is the highest in the Krotoszyce Municipality - good level (synthetic metaindex 2.485), and the lowest in the Wąsosz Municipality - very weak level (metaindex 0.774).

Only $20 \%$ of the analysed municipalities show good level of socio-economic conditions. The remaining study objects $(80 \%)$ are distinguished by weak or very weak level of the conditions. None of the analysed municipalities shows very good level of socioeconomic conditions.

No correlations were determined between the surface area of the implemented consolidation works of agricultural land and the synthetic index of socio-economic conditions (the correlation coefficient between the variable amounted to 0.147). Nonetheless, notice that consolidations are particularly implemented in municipalities where the level of socio-economic conditions shows weak or very weak level.

According to the authors, formulating more unambiguous conclusions requires further research on agricultural land consolidations and their determining factors.

\section{REFERENCES}

[1] Thomas, J.. Attempt on systematization of land consolidation approaches in Europe, ZfV - Zeitschrift für Geod., Geoinform. und Landmanagement, Germany, vol. 3, 2006.

[2] Pasakarnis, G. et al.. Factors influencing land consolidation success: Lessons learned in Lithuania, In Hepperle, E. et al. (Edt.): Land Management, Potential, Problems and Stumbling Blocks, Hochschulverlag, Germany, 2013.

[3] Hartvigsen, M.. Experiences with land consolidation and land banking in Central and Eastern Europe after 1989, Land Tenure Working Paper 26, FAO, 2015.

[4] Lisec, A., Primozic, T., Ferlan, M., Sumrada, R., Drobne, S.. Land owners' perception of land consolidation and their satisfaction with the results-Slovenian experiences, Land Use Policy 38, pp 550-563, International, 2014.

[5] Hartvigsen, M., Gorgan, M., Palmer, D.. (2013): Experiences with Land Reform and Land Consolidation in Moldova, FAO Land Tenure Journal, vol. 22, 2012.

[6] Dudzińska, M.. 2015. Potencjał uwarunkowań przestrzennych gospodarstw w gminach województwa dolnośląskiego, na obszarze których zrealizowano scalenia gruntów rolnych, Acta Sci. Pol. Administratio Locorum, vol. 19, Poland, 2015.

[7] Ministerstwo Rolnictwa i Rozwoju Wsi Departamentu Rozwoju Obszarów Wiejskich ROWWRT-JW(JS)-051-4/15(3988), wniosek o udostępnienie informacji publicznej z zakresu scaleń gruntów, Poland, 2015.

[8] Jędrejek, A., Szymański, L., Woch, F.. Evaluation of the plot size (farm land) of family agricultural holdings and the needs for land consolidation in Poland, Infrastruktura i Ekologia Terenów Wiejskich, vol. IV/1, pp 1111-1125, Poland, 2014. 
[9] Strategia rozwoju województwa dolnośląskiego do 2020 roku. Diagnoza społeczno - gospodarcza regionu, Wrocław.

http://www.umwd.dolnyslask.pl/fileadmin/user_upload/_temp_/02._SRWD_do_202 0_r._-_Zalacznik.pdf - dostęp 12.11.2015, Poland, 2005.

[10] Parysek, J.. Polskie miasta na przełomie XX i XXI wieku, Rozwój i przekształcenia strukturalne, Poland, 2005.

[11] Grabiński, T., Wydymus, S., Zeliaś, A. 1989. Metody taksonomii numerycznej w modelowaniu zjawisk społeczno-gospodarczych, Poland, 1989.

[12]Heffner, K., Gibas, P.. Analiza ekonomiczno-przestrzenna, Wyd. Akademii Ekonomicznej w Katowicach, Poland, 2007. 